\title{
Model of global responsibility formation among students
}

\author{
Eugenia Yadrikhinskaya ${ }^{1,}$, Malika Ashimova ${ }^{2}$, Aizhan Shynybekova $^{2}$ and Almagul Tastemirova ${ }^{2}$ \\ ${ }^{1}$ North-Eastern Federal University named after M.K. Ammosov, 56 Belinskiy Street, Yakutsk, 677000, Russia \\ ${ }^{2}$ Zhetysu University named after I. Zhansugurov, 187 A Zhansugurov Street, Taldykorgan, 040009, Kazakhstan
}

\begin{abstract}
The article discusses the need for the formation of global responsibility among students as a factor of successful adaptation in the conditions of uncertainty and constant challenges of global society. Moreover, global responsibility is considered to be the basic element of sustainable development. A retrospective analysis of the concept of global responsibility is given. The evolution of the scale of responsibility from personal to global is shown. The authors represent the model of global responsibility formation among students. It is believed that global responsibility as a pedagogical problem should be considered within the framework of theory of global competence.
\end{abstract}

\section{Introduction}

Nowadays when the world is becoming more and more interconnected and interdependent, the challenges and opportunities facing humanity are becoming more global. The number of global problems that should be solved is growing every year. In 2021 in addition to the problems of climate change, depletion of natural resources, migration, poverty and illiteracy, the problems of the pandemic and post-pandemic life appeared. Tackling global challenges and solving global problems require competent professionals, citizens and leaders. In this regard, all students need to develop global thinking and form global responsibility.

Recently, teachers have also developed an interest in global responsibility. Perhaps this fact was facilitated by the UN Sustainable Development Concept for 20152030, according to which by 2030 it is necessary for all students to acquire the knowledge and skills necessary to promote sustainable development [UNESCO] and the Strategy for the Development of Education in the Russian Federation until 2025 year where great attention is paid to the upbringing of a free personality, ready to bear responsibility for their actions, thoughts and actions. Thus, if until recently the fate of the world depended on the decisions of several people, now it is the responsibility of all people. And as the world becomes more interconnected, there is a need to educate students on how to become active global citizens. The main quality of a citizen of the world, in our opinion, is his global responsibility.

The aim of the article is to give the definition to the concept of global responsibility and represent the model of the global responsibility formation among students.

\section{Methods}

To find out what global responsibility is we used the method of literature analysis (153 scientific works were used). We performed the development of the concept in retrospective. In addition, the method of modeling was used. The model of global responsibility formation among students is given.

\section{Literature Review}

The concept of responsibility itself is not new. A retrospective analysis of the literature showed a gradual change in the scale of responsibility: from personal to global. In philosophy, Aristotle [1] was one of the first to study responsibility, considering personal responsibility as a duty. During the Age of Enlightenment, the idea of responsibility was reflected in the works of R. Descartes [2] and T. Hobbes [3], who laid the foundation for the concept of social responsibility, according to which a person is responsible to society and must think about the consequences of his actions. According to L.V. Bayborodova, social responsibility is the most important indicator of a person's social maturity, his civic consciousness, activity and independence. The author understands social responsibility as a volitional quality, expressed in the readiness of the individual to consciously assume certain obligations to society and the ability to actively implement these obligations in any life situations [4].

The idea of cosmic responsibility was presented in the works of Russian cosmist philosophers N.A. Berdyaev [5], V.I. Vernadsky [6], and K.E. Tsiolkovsky [7]. V.I Vernadsky wrote that a person, being endowed with reason, must "consciously and with the least harmful consequences change nature, make the biosphere suitable for life for all subsequent generations". Of particular interest is the work of $\mathrm{H}$. Jonas "The Principle of Responsibility: The Experience of Ethics for a Technological Civilization" [8], in which

Corresponding author: yadrikhinskaya_e@mail.ru 
the author traces the transition of responsibility from the individual level to a higher level - global and introduces the term "global responsibility". The scientist believes that a person should act in such a way that the result of his actions is "in accordance with the continuity of righteous human life on Earth", i.e. the place of "reasonable man" should be taken by a "responsible person".

So, as we can see in the 20th century, the classical Kant's [9] moral theory of responsibility is shifted by the neo-classical approach, known as Ethics of Responsibility. The center of responsibility has shifted towards the personality, its responsibility for others (J.-P. Sartre [10]), for himself (M.M. Bakhtin [11]), for the Other (E. Levinas [12]), for all living things (H. Jonas), the ability of a person to "act and be included in discourse" (Yu. Habermas [13]), the readiness to "be responsible for effects of risky solutions" (Z. Bauman [14]). "A person who decides on something and realizes that he chooses not only his own being, but that he is also a legislator, choosing simultaneously with himself all humanity, must have the feeling of complete and deep responsibility ", - believes J.-P. Sartre. When a person expands the circle of those for whom and for which he is responsible, he overcomes the "partial" (M. M. Bakhtin) of his existence and becomes "responsible for all and everything what happened in past, what is happening now and will happen in future". Seeing the person in relationship with other people, E. Levinas recognized the significance of the Other. He wrote about the openness to the Other and responsibility for the Other, underlying freedom and openness in a situation of "reference to the Other", that is, "face to face".

In the neo-classical concept of responsibility special significance acquires the question of harmonizing the interests of people, of the ratio of personal and public. Discussing the transformation of the relationship between the individual and society, about the "responsible choice" of the individual, A. A. Guseinov emphasizes that "now a moral boundary is not a norm, but a decision of a person". In other words, the moral decision is made by the individual himself as "a moral autonomous subject". The individual is responsible for the implementation of his meanings ("responsibility of meaning", J.-L. Nancy [15]) and the realization of values.

Thus, responsibility as a fundamental sociocultural principle carries the prospect of fundamental changes in the attitude towards a person, society, nature. This corresponds to the expansion of the horizon of responsibility, vector responsibility, takes all more often character collective responsibility. Occurring changes life of people, understanding of socially significant events and their consequences became the impetus for a deeper analysis of the problem of responsibility in modern ethics, before all in such its concretizations as bioethics, social ethics, environmental ethics and others.

Borders of responsibility become mobile, horizon responsibility is expanding. Responsibility turns out to be an important regulator, human actions on political and the legal arena, in medicine, education and other socially significant spheres of human activity.

The last quarter of the twentieth century is a period of rapid development of Ethics of responsibility, "ethics for technogenic civilization", presented in the works of K. Bayerts [16], H. Jonas, V. A. Kanke [17] and others [18-21]. Analysis of the modern situation, characterized by the almost unlimited power of man over nature and his own essence, showed a number of new objects of moral responsibility. If in classical concept responsibility was limited to communication between people, then in the neo-classical concept, including the responsibility of man and humanity for Nature existence, for its integrity, a responsibility for future generation, as well as for the remote consequences of human activity.

\section{Results}

Based on the literature analysis we are able to give the definition to the concept of global responsibility.

Global responsibility is a moral attitude of a person, based on a deep understanding of the meaning and consequences of his activities on the planet. Global responsibility is a way of maintaining peace (the integrity of society and social harmony, social justice and improving public relations) and preserving the Earth as a common Home for all inhabitants of the planet, where people are one family, and everyone should actively participate in the world order. Global responsibility is responsibility of everyone for everything in front of everybody in past, present and future.

The basis of the process of global responsibility formation is the development of global thinking, a holistic perception of the world and man as its integral part and the highest value, the formation of a sense of personal responsibility for solving global issues affecting every inhabitant of the Earth, environmental education, care about the life of all living beings on Earth, as well as the formation of such an important moral quality as responsibility to future generations. The aim is to familiarize students with human achievement and values. It promotes ethical education and fostering respect for human dignity, instilling in him a sense of global solidarity 
Table 1. The model of global responsibility formation among students.

\begin{tabular}{|c|c|}
\hline \multicolumn{2}{|r|}{ Conceptual part } \\
\hline Aim & To form global responsibility among students \\
\hline Tasks & $\begin{array}{l}\text {-To create positive attitude towards responsible behavior in global society; } \\
\text { - To promote global thinking and global competence; } \\
\text { - To set up conditions for person's self-development; his/her readiness to make globally responsible } \\
\text { decisions. }\end{array}$ \\
\hline Principles & Consistency, continuity, consciousness, independence \\
\hline Criteria & Cognitive, motivational, activity-based \\
\hline Conditions & $\begin{array}{l}\text { 1.Organization of the pedagogical process to teach students basics of global responsibility (cognitive } \\
\text { component); } \\
\text { 2.To ensure integration of educational and social activities (activity-based component); } \\
\text { 3. To create educational environment for global responsibility development (motivational component) }\end{array}$ \\
\hline \multicolumn{2}{|r|}{ Content part } \\
\hline Types & Internal/ external, individual/ collective \\
\hline Functions & Value-orienting, regulating, modifying \\
\hline Components & Cognitive, motivational, activity-based \\
\hline \multicolumn{2}{|r|}{ Process part } \\
\hline Stages & $\begin{array}{l}\text {-Informing about the essence of rights and obligations, about norms and rules of human behavior in } \\
\text { society and how to regulate it } \\
\text {-Actualization of life experience } \\
\text {-Social motivation for globally responsible behavior } \\
\text {-Moral implementation for globally responsible actions } \\
\text {-Inspiration to consciously regulate own actions } \\
\text {-Creating situations requiring conscious choice } \\
\text {-Decision-making and assessment of its consequences } \\
\text {-Consolidation of the experience gained in various forms of socially significant activities (scientific } \\
\text { research, cultural and educational, social design, student self-government, public and youth } \\
\text { organizations), including in the activities of the social and professional group }\end{array}$ \\
\hline Result & Global responsibility formation \\
\hline
\end{tabular}

\section{Discussion}

To make the process of global responsibility formation among students effective the following tasks must be set for a higher educational institution:

1) to form a positive attitude towards the global responsible behavior in general and in a specific area of professional activities, conscious perception and acceptance presented by society, social and professional community, specific society of requirements;

2) to form in future specialists knowledge about global responsibility, about the essence of rights and obligations, values, morality, norms of behavior, morality, permissible and unacceptable social actions; it is extremely necessary to develop global thinking and global competence among the students.

3 ) to create conditions that ensure the development and self-development of the personality of the future specialist.

Global thinking can be understood as thinking based on the principles of equality, justice and common sense. A person with global thinking respects the law and lives according to nature in harmony with others. He is responsible for his actions and is responsible for their consequences, i.e. has a global responsibility.

The structure of global responsibility appears to us as the relationship of three components:
1) cognitive (a system of knowledge assimilated by a person about global responsibility, about the essence of rights and obligations, about norms and rules of human behavior in global society);

2) motivational (motives of global responsible behavior, moral aspirations for the realization of responsible actions, the urge to consciously regulate own actions);

3 ) activity-based (the student's readiness make decisions, evaluate to determine their consequences, to determine the necessary restrictions in the conducting based on a formed worldview and developed self-awareness).

There are different types of global responsibility: external, internal, individual, collective responsibility depending on the subject of responsible actions. Integrating with each other, they form a new concept of "global responsibility" in terms of content and structure, which can manifest itself at various levels: personality (micro level), social group (meso level), a specific society (macro level), and humanity as a whole (mega level).

At the same time, global responsibility performs various functions:

1) Value-orienting (meaning-forming) orientates in the norms, values, traditions of global society.

2) Regulating expresses a complex of moral requirements and ways of regulating behavior in a global community. 
3) Modifying contributes to the formation of existing knowledge in beliefs, belief system on the world around you, on yourself and your place in this world.

Implementation of pedagogical conditions for the formation of global responsibility among students is possible on the basis of adherence to the classical principles of didactics, which include the principles of consistency, continuity, conscientiousness and independence.

Principles of global responsibility formation:

- consistency, which involves the creation of a system for the formation of students' global responsibility, the interconnectedness of all elements;

- continuity, providing for the gradual formation of global responsibility, passing through a number of stages, consolidating the skills acquired at the previous stage;

- conscientiousness and independence, providing the formation of the correct attitude to the surrounding reality and the corresponding beliefs. In the process of studying only knowledge is transmitted and each person (individual) develops his/her beliefs independently, that is, consciously.

The principles of teaching orient the organizers of the educational process, depending on the content of the academic subject, to choose forms, methods, and techniques. And here each principle of teaching becomes a didactic locomotive of the movement of the faculty composition to the results of vocational education.

The process of forming students' global responsibility includes three interrelated stages:

- informing students about the essence of rights and obligations, about the norms and rules of human behavior in global society and ways of regulating it;

- actualization of students' life experience, motivation of globally responsible behavior, moral aspirations to the implementation of responsible actions, the urge to consciously regulate their actions, the creation of situations requiring a conscious behavior, decisionmaking

-consolidation of the experience gained in various forms of socially significant activity (research, cultural and educational, social design, student government, public and youth organizations), inclusion in the activities of social and professional groups.

Based on the analyzed structure components of global responsibility, we have chosen the following criteria for the formation of global responsibility:

1) cognitive (understanding of rights and responsibilities, norms and rules of behavior, focus on them in the process of activity);

2) motivational (the formation of motives for globally responsible behavior);

3) activity-based (awareness of the nature of actions, the degree of consistency and success in the execution of educational and social work).

\section{Conclusions}

Thus, the creation of a model of the formation of global responsibility among students and its implementation in the organization of the educational process allows us to draw the following conclusions:

Analysis of the educational process of a professional training of students allows us to talk about the presence of the potential of an educational institution of higher professional education, including:

- to form in future specialists knowledge about global responsibility, rights and obligations, values, norms of behavior, morality, about permissible and unacceptable actions in global society;

- to develop a positive attitude towards globally responsible behavior in general and in a specific area of professional activity;

- to create conditions that ensure the development and self-development of the personality of the future specialist, his readiness fully and morally on the basis of cooperation and partnership to build joint activities in a team.

Using the potential of an educational institution of higher professional education in the formation of global responsibility of students can be implemented within the framework of the built model, which is based on the principles of consistency, continuity, conscientiousness and independence.

In the model under consideration, the formation of global responsibility occurs with the predominant use of social design.

The criteria for the formation of social responsibility among students are:

cognitive (correct understanding of the norms and rules of economic behavior, orientation towards them in the process of activity);

motivational (the formation of motives globally responsible behavior);

activity-based (awareness of the nature of actions, the degree of consistency and success in the performance of educational and social work).

In conclusion we would like to stress that a stable and dynamically developing society can only be built by educated people who are able to respond flexibly and intelligently to constant and rapid changes in the world, who have a developed sense of responsibility both for their own destiny, the destiny of their country, and for the destiny of humanity and the planet. The formation of personal and global responsibility in the context of the globalization of education is of great importance, since it predetermines a responsible attitude of a person to his/her actions and actions, ensuring the prediction of their consequences for him/her, society, the state, and the planet as a whole.

\section{References}

1. McKeon R. (Ed.) The basic works of Aristotle, (Modern library classics, 2001)

2. Descartes R., A discourse on the method. (Oxford: Oxford University Press, 2006)

3. T. Hobbes, On the citizen. (Cambridge: Cambridge University Press, 1997) 
4. L.V. Bayborodova, V.V. Belkina, A.V. Zolotareva, L.N. Serebrennikov, A.M. Khodyrev, Development of learners' democratic culture, Social Sciences (Pakistan), 11(20), (2016)

5. N.A. Berdyaev, About the appointment of a person. (Moscow: Respublika, (1993)

6. V.I. Vernadsky. Diaries, letters, a fragment from the works (Moscow: Nauka, 1978)

7. K. Tsyolkovsky, The future of the Earth and humanity. (Kaluga: edition of the author, 1928)

8. Jonas H., The Imperative of Responsibility: In Search of Ethics for the Technological Age, (University of Chicago Press, 1984)

9. Wood A.W., Kantian Ethics (Stanford University, California, 2007)

10. S. Jean-Paul Existentialism Is a Humanism. (New Haven, CT: Yale University Press, 2007)

11. S. Petrilli, Dialogue, responsibility and literary writing: Mikhail Bakhtin and his Circle, Semiotica, 2016 (213), 307-343, (2016) https://doi.org/10.1515/sem-2015-0094

12. J. Bloechl (Ed.), The Face of the Other and the Trace of God: Essays on the Philosophy of Emmanuel Levinas, (Fordham University Press; 1st edition, 2000)

13. Habermas, The Philosophical Discourse of Modernity: Twelve Lectures, (The MIT Press, 1990)

14. Z. Bauman, Globalization: The Human Consequences, (Columbia University Press, 1998)

15. J-L. Nancy, The Experience of Freedom (Meridian: Crossing Aesthetics), (Stanford University Press; 1st edition, 1994)

16. Bayertz K., Solidarity. Philosophical Studies in Contemporary Culture, vol 5. (Springer, Dordrecht. 1999) https://doi.org/10.1007/978-94$\underline{015-9245-1 \_1}$

17. V. A. Kanke, The Metascientific and Philosophical Bases of Information Ethics. Autom. Doc. Math. Linguist. 52, 1-6, (2018). https://doi.org/10.3103/S0005105518010041

18. L.Sidorova, N.Alexeeva, Z. Emelianova, L. Olesova The Role of the Yakut TESOL Conferences for the Professional Development of EFL Teachers in Yakutia. Lecture Notes in Networks and Systems, 131 ( Springer, Cham., 2020) https://doi.org/10.1007/978-3-030-47415$\underline{7} 7$

19. V. Stiopin, Modern Technologies and Perspectives of Civilization". Technology and Cultural Values: On the Edge of the Third Millennium, pp. 17-25. (Honolulu: University of Hawaii Press, 2003), https://doi.org/10.1515/9780824844967-003

20. Vafa Ghazavi, Agency, global responsibility, and the speculations of ordinary life, Critical Review of International Social and Political Philosophy, (2021). DOI: 10.1080/13698230.2021.192137

21. Assessing Schools for Generation $\mathrm{R}$ (Responsibility), 41, (2014) 